\title{
SISTEM INFORMASI PENGELOLAAN SERVICE TOKO KOMPUTER BERBASIS QRCODE
}

\author{
Agung Septyanto Putra \\ Program Studi Informatika Universitas Muhammadiyah Surakarta \\ Surakarta, Indonesia1200140103@ student.ums.ac.id \\ Heru Supriyono \\ Program Studi Informatika Universitas Muhammadiyah Surakarta \\ Surakarta, Indonesia Heru.Supriyono@ ums.ac.id
}

\begin{abstract}
Abstrak - Semakin banyaknya toko servis komputer, membuat masing-masing pemilik usaha servis komputer berusaha meningkatkan layanan kepada pelangganya. Semakin banyaknya pelanggan pada sebuah tempat servis komputer penggunaan telepon dan sms menjadi kurang cepat dan efektif memberikan status terbaru barang pelanggan. Diharapkan dengan adanya sistem informasi pengelolaan servis komputer berbasis web, dapat membantu untuk meningkatkan kepercayaan pelanggan kepada tempat servis tersebut. Menggunakan metode waterfall dalam pembuatan, sistem ini dibangun menggunakan bahasa pemrograman HTML,CSS dan PHP 7.1. Sistem informasi ini dapat mencetak Quick Response Code (QRCODE) yang terdapat dalam nota, sehingga untuk update informasi pelanggan bisa melakukan pemindaian langsung. Berdasarkan pengujian pelaku usaha servis komputer menyadari sistem dapat meningkatkan pelayanan, semua fungsi sistem bekerja dengan baik berdasarkan pengujian blackbox, sistem informasi yang mudah dipahami dan digunakanlah yang dapat menarik pelauku usaha servis komputer untuk menggunkan sistem informasi berbasis web.
\end{abstract}

\section{Kata kunci-Komputer,Servis,PHP, QRCODE, Blackbox}

\section{Pendahuluan}

Perkembangan zaman pada saat ini membuat komputer menjadi sebuah barang yang sangat dibutuhkan untuk melaksanakan setiap aktivitas di semua bidang. Sebuah instansi bahkan tidak dapat menjalankan beberapa kegiatan tanpa adanya komputer. Memiliki sebuah komputer tidak menjamin seseorang maupun sebuah instansi memiliki staff yang memiliki pengetahuan dan kemampuan dalam menangani setiap masalah yang ada pada komputer. Hal ini dijadikan peluang bagi beberapa orang yang memiliki kemampuan dalam menangani masalah pada komputer dengan membuka usaha servis komputer. Semakin banyaknya toko servis komputer, membuat masing-masing pemilik usaha servis komputer berusaha meningkatkan layanan kepada pelangganya. Beberapa tempat servis menggunakan sarana telepon dan sms untuk menghubungi dan memberikan informasi kepada pelanggan tentang status perangkat pelanggan. Semakin banyaknya pelanggan pada sebuah tempat servis komputer penggunaan telepon dan sms menjadi kurang cepat dan efektif memberikan status terbaru barang pelanggan. Sehingga di temukan kasus pelanggan yang harus jauh-jauh mendatangi toko servis hanya untuk mengetahui keadaan perangkatnya, kasus yang seperti ini dapat membuat kepercayaan pelanggan menurun.

Perkembangan teknologi saat ini berkembang menuju kearah penyebaran informasi dengan menggunakan website. Teknologi informasi membantu mempersingkat, dan mempermudah pelayanan masyarakat ${ }^{[6]}$. Setiap organisasi harus menyesuaikan sistem informasinya dengan kebutuhan pemakainya $^{[8]}$. Penggunaan sistem informasi juga merupakan langkah yang efisien untuk memecahkan masalah diatas.Teknologi aplikasi yang digunakan harus dibuat 
menggunanakan teknologi yang memberikan kemudahan dalam implementasi, penggunaan, maupun kemudahan pengembangan lanjut di kemudian hari ${ }^{[9]}$. Sementara itu seiring dengan perkembangan zaman telah ditemukan pemindai Quick Response (QR) code yang dapat menyimpan informasi lebih besar di bandingkan kode batang ${ }^{[1]}$. QR code adalah kode bar dua dimensi dimana informasi diwakili oleh titik hitam dan putih ${ }^{[4]}$.Alasan penggunaan $\mathrm{QR}$ code adalah kemampuanya untuk digunakan pada semua sistem perangkat lunak, seperti pada aplikasi halaman web, smartphone, tablet dan komputer ${ }^{[3]}$.

Dengan menggunakan permasalahan diatas penulis memiliki gagasan untuk membuat sistem informasi berbasis web yang terkomputerisasi. Pengerjaan dengan menggunakan sistem komputeriasai dapat memudahkan dan menghemat waktu serta menghemat biaya ${ }^{[7]}$. Pelanggan nantinya hanya akan mengakses sebuah halaman website dan menuliskan kode dalam nota barang atau pelanggan dapat melakukan pemindaian terhadap $\mathrm{QR}$ code yang juga tercetak dalam nota. Pembuatan sistem informasi dalam penelitian ini juga tidak ditujukan hanya untuk pelanggan yang melakukan servis, namun juga kepada pemilik tempat servis komputer sebagai arsip yang tersimpan dalam database. Diharapkan dengan adanya sistem informasi pengelolaan servis komputer berbasis web, dapat membantu untuk meningkatkan kepercayaan pelanggan kepada tempat servis tersebut.

\section{METODE}

Sistem informasi ini dikembangkan selain untuk memberikan pelayanan dan informasi kepada pelanggan, sistem informasi ini juga berfungsi untuk pengarsipan data-data pelanggan yang menggunakan jasa servis pada toko tersebut. Data yang disimpan dapat dicetak oleh pemilik toko dalam bentuk cetakan kertas, sehingga pemilik toko lebih mudah dalam melihat laporan transaksi yang dimiliki toko servis komputer.Sistem informasi ini dirancang dengan menggunakan metode waterfall. Metode air terjun atau yang sering disebut metode waterfall sering dinamakan siklus hidup klasik (classic life cycle), dimana hal ini menggambarkan pendekatan yang sistematis dan juga berurutan pada pengembangan perangkat lunak, dimulai dengan spesifikasi kebutuhan pengguna lalu berlanjut melalui tahapan-tahapan perencanaan (planning), permodelan (modeling), konstruksi (construction), serta penyerahan sistem ke para pelanggan/pengguna (deployment), yang diakhiri dengan dukungan pada perangkat lunak lengkap yang dihasilkan ${ }^{[5]}$. Metode waterfall banyak digunakan untuk pengembangan perangkat lunak multimedia terutama di kalangan mahasiswa. Penggunaan ini sepertinya sesuai dan tidak ada kendala dalam implementasinya ${ }^{[2]}$. Pada perencanaa awal penulis mencoba menggambarkan cara kerja sistem, melalui gambar arsitektur dari sistem informasi ini, seperti pada gambar 1 .

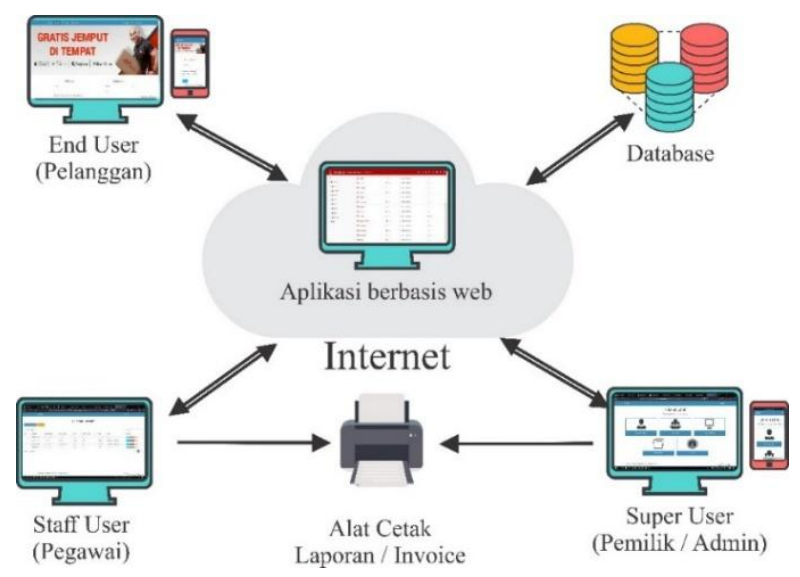

Gambar 1. Arsitektur sistem

\subsection{Analisis Kebutuhan}

Dalam proses pembuatan penulis memerlukan beberapa alat yang digunakan untuk membuat sistem informasi pengelolaan servis komputer berbasis QR code, seperti yang dijelaskan pada Tabel 1 . 
Tabel 1. Kebutuhan Perangkat Keras dan Kebutuhan Perangkat Lunak

\begin{tabular}{|c|c|}
\hline $\begin{array}{l}\text { Perangkat Keras } \\
\text { (Hardware) }\end{array}$ & $\begin{array}{l}\text { Perangkat Lunak } \\
\text { (Software) }\end{array}$ \\
\hline $\begin{array}{l}\text { a. Laptop } \\
\text { Asus } \\
\text { x550vx } \\
\text { Intel Core } \\
\text { i7 } 6700 \mathrm{HQ} \\
\text { CPU } 2.6- \\
3.5 \mathrm{GHz}, \\
\text { RAM } 8 \mathrm{~GB}, \\
\text { Hardisk } \\
\text { 1TB } \\
\text { b. Smartphone } \\
\text { dengan OS } \\
\text { Andoroid } \\
\text { c. Printer }\end{array}$ & $\begin{array}{ll}\text { a. } & \text { Sublime Text } \\
& 3 \\
\text { b. XAMPP } \\
\text { c. Adobe } \\
\text { Dreamweaver } \\
\text { CC } 2017 \\
\text { d. Mozilla } \\
\text { Fiefox } \\
\text { e. Nitro Pro }\end{array}$ \\
\hline
\end{tabular}

\subsection{Perancangan}

Pada tahap perancangan (design) sistem penulis membuat rancangan use case diagram , activity diagram, dan pembuatan database. Selanjutnya dengan membuat rancangan tampilan yang akan digunakan oleh sistem nantinya.

\section{- Use Case Diagram}

Use case diagram akan menjelaskan interaksi yang terjadi antara aktor dengan sistem. Perancangan use case pada sistem ini menggunakan 3(tiga) aktor yaitu, Super User, Staff User, End User.

Pertama adalah Super User hak akses ini diberikan kepada pemilik tempat servis komputer. Hak akses yang dimiliki Super User dapat dilihat pada Gambar 2.

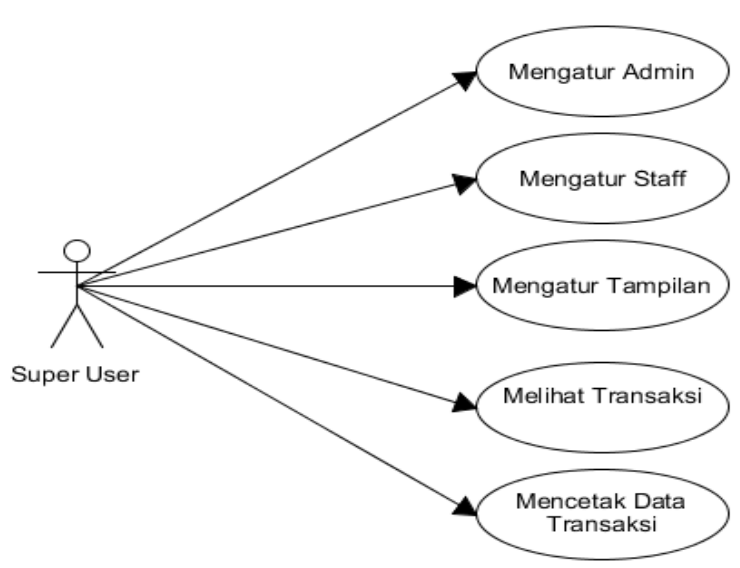

Gambar 2. Use Case Diagram Super User

Kedua adalah Staff User hak akses ini digunakan untuk mengakses halaman pengelolaan transaksi dan perubahan informasi status barang pelanggan, hak akses staff user diberikan kepada pegawai yang melakukan serah terima barang yang akan di servis. Hak akses yang di berikan kepada staff user dapat dilihat pada Gambar 3.

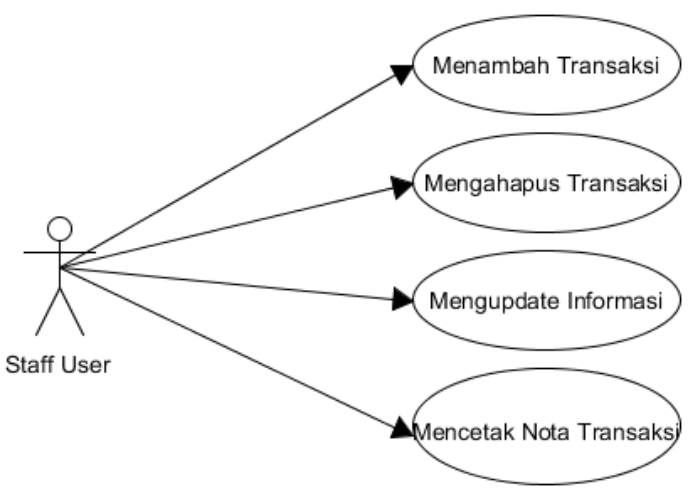

Gambar 3. Use Case Diagram Staff User

Ketiga adalah End User, pelanggan adalah End User dalam sistem ini , sistem memberikan informasi kepada pelanggan, dan pelanggan mengakses sistem. Pelanggan memiliki hak akses yang dapat dilihat pada Gambar 4. 


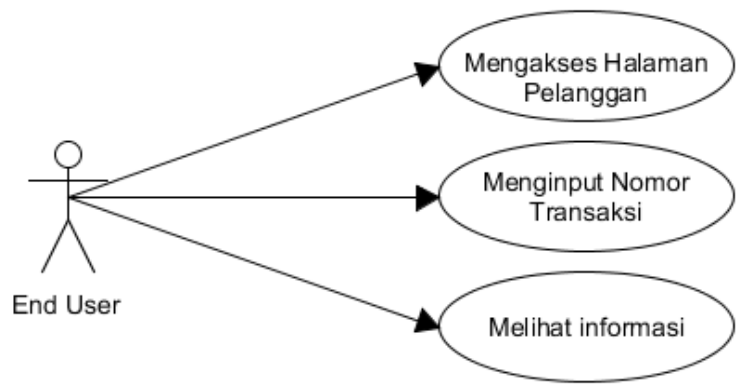

Gambar 4. Use Case Diagram End User

- Activity Diagram

Activity diagram menggambarkan aktivitas yang dilakukan 3 (tiga) aktor kepada sistem. Seperti pada Gambar 5 yang menggambar aktivitas Staff User melakukan input data barang pelanggan akan di servis.

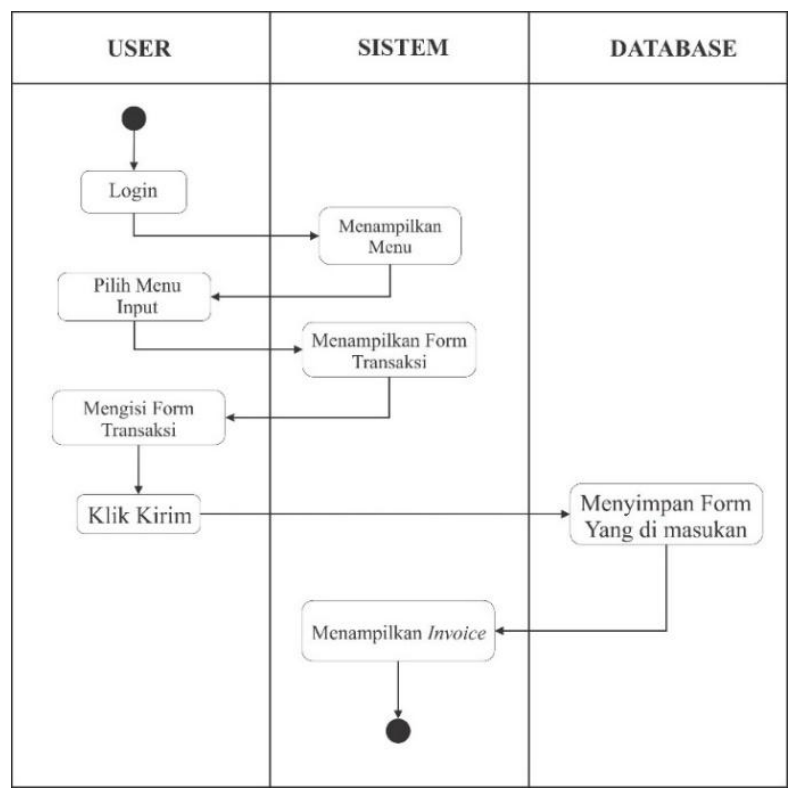

Gambar 5. Activity diagram input data barang

- Pembuatan Database

Pembuatan database digunakan untuk menyimpan data pada sistem informasi pelayanan servis komputer ini menggunakan 3 (tiga) tabel, st_user yang digunakan untuk menyimpan data pengguna yang akan login pada halaman admin, st_user yang digunakan untuk menyimpan data pengguna yang akan login pada halaman transaksi, tulisan untuk menyimpan data informasi pada halaman utam pengguna, tabel gambar untuk menyimpan data gambar dan tabel transaksi untuk menyimpan data transaksi, seperti pada Gambar 6.

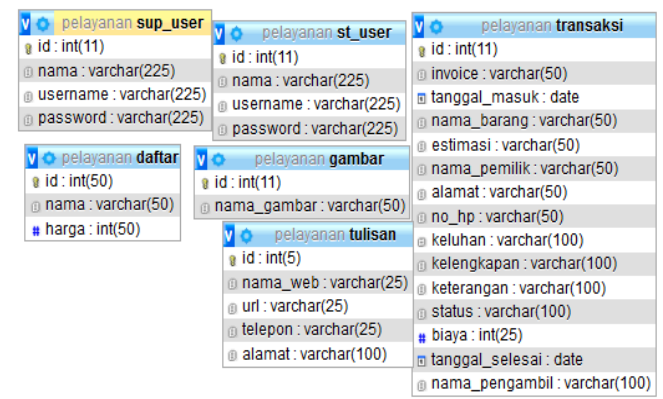

Gambar 6. Pembuatan Database.

- Rancangan Tampilan Awal

Rancangan tampilan awal menggambarkan user interface sistem informasi pelayanan servis komputer. Rancangan awal tampilan yang diakses pengguna (End User), berisi tentang ,form untuk melakukan cek barang, form untuk melihat daftar biaya servis yang disediakan toko, kontak telepon toko, dan gambar slide, yang digunakan toko untuk promosi. Rancangan dapat dilihat pada Gambar 7.

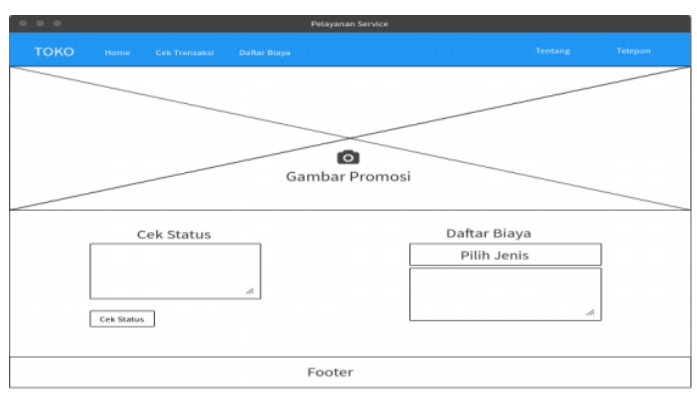

Gambar 7. User Interface utama. 


\section{HASIL DAN PEMBAHASAN}

\subsection{Hasil}

Hasil dari sistem yang di rancang menghasilkan sebuah sistem infromasi berbasis web yang dapat diakses melalui komputer dan smartphone. Sistem yang dibuat dapat memberikan informasi terbaru tentang status barang milik pelanggan yang dapat di akses dengan cepat melalui proses memindai kode QR. Dari sisi pemilik tempat servis , sistem ini juga dapat membantu untuk penyimpanan data transaksi yang disimpan secara digital kedalam sebuah database.

Halaman utama pelanggan, halaman yang diakses oleh pelanggan ini berisikan informasi yang diberikan oleh pemilik tempat servis komputer. Pada halaman ini terdapat 2 (dua) menu utama yaitu menu untuk memasukkan nomor transaksi yang digunakan untuk menuju halaman status barang dan menu pilihan untuk melihar daftar biaya, dapat dilihat pada gambar 8 .

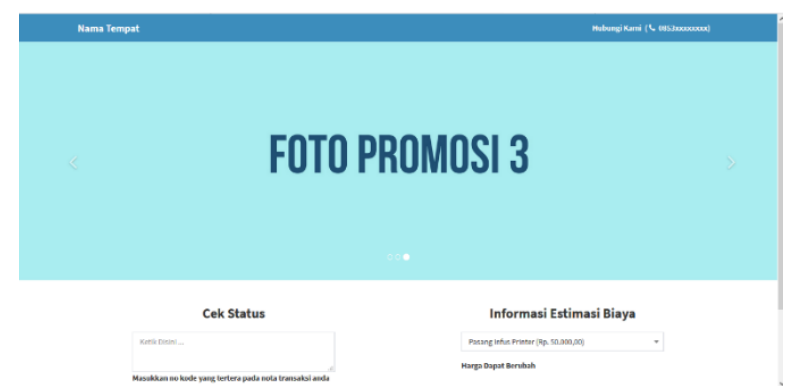

Gambar 8. Tampilan halaman utama pelanggan

Setelah memasukkan nomor transaksi atau dengan melakukan pemindaian terhadap kode QR pelanggan akan diarahkan kehalaman status barang seperti contoh pada gambar 9 .

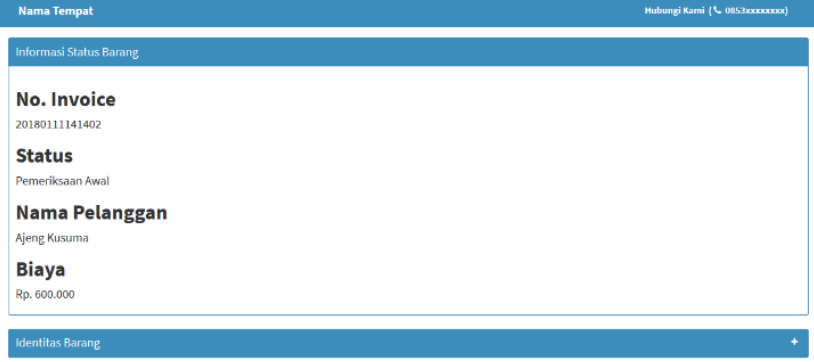

Gambar 9. Contoh dari halaman status barang.

Pemilik tempat servis yang menggunakan sistem informasi ini dapat mengakses halaman utama transaksi dan admin melalui halaman login seperti pada gambar 10 .

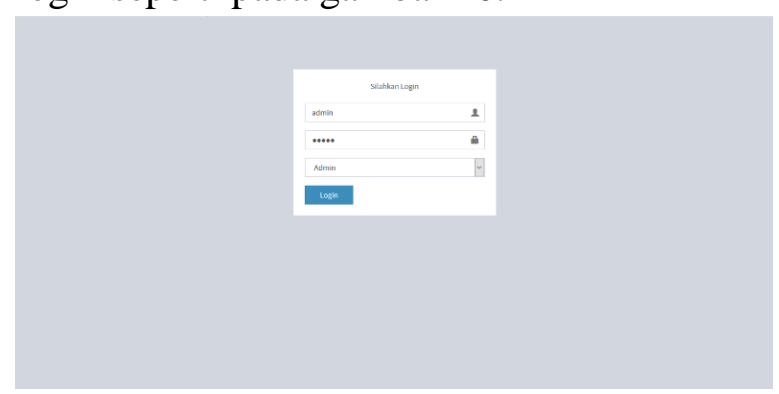

Gambar 10. Halaman login.

Halaman utama admin hanya dapat diakses oleh admin dengan username dan password yang telah tersimpan. Halaman utama berisikan menu yang akan berguna untuk melakukan manajemen sistem informasi ini, diantaranya pengaturan admin, pengaturan staff, pengaturan tampilan , serta menu cetak laporan dan tentang. Tampilan halaman utama admin dapat dilihat pada gambar 11 .

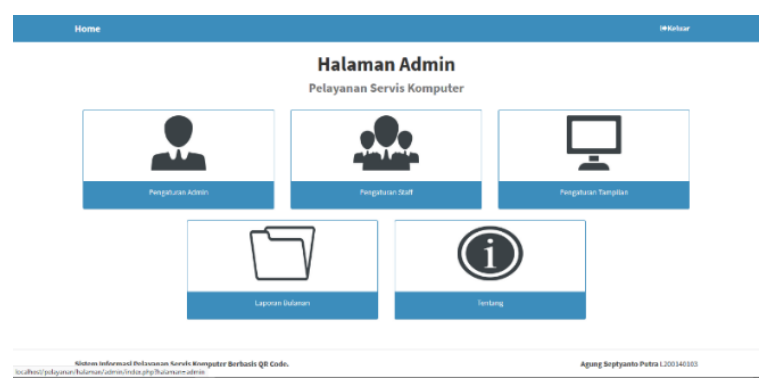

Gambar 11. Halaman utama admin. 
Menu pengaturan admin di gunakan untuk menambahkan,mengedit dan menghapus username dan password yang digunakan untuk login masuk kedalam halaman admin. Menu pengaturan staff digunakan untuk menambahkan, mengedit dan menghapus username dan password yang digunakan untuk login masuk kedalam halaman transaksi. Menu pengaturan tampilan digunakan unttuk melakukan perubahan informasi yang ada pada halaman utama pelanggan, mulai dari mengatur nama web, mengedit alamat yang akan digunakan untuk kode QR, nomor telepon, alamat, menambah daftar menu dan mengganti gambar. Menu laporan bulanan digunakan untuk mencetak laporan transaksi dan menu tentang yang berisi informasi tambahan.

Halaman utama transaksi hanya dapat diakses dengan login sebagai staff, dengan terlebih dahulu menambahkan username dan password untuk login. Pada halaman transaksi terdapat beberapa tombol seperti menambahkan transaksi baru, mengupdate status terbaru barang, memindahkan data transaksi ke dalam transaksi selesai, menghapus data, melihat detail barang dan terdapat tombol untuk menuju kedalaman halaman transaksi selesai. Tampilan dapat dilihat pada gambar 12 .

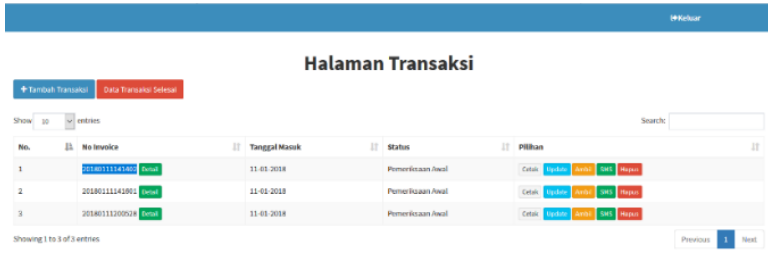

Gambar 12. Tampilan halaman transaksi selesai.

Pada proses cetak transaksi digunakan ekstensi Microsoft Print to PDF, didalam lembaran transaksi terdapat informasi barang, identitas pemilik barang, informasi pemilik tempat servis komputer dan sebuah kode QR yang jika di pindai akan mengarahakan langsung ke halaman status barang. Sedangkan script program untuk mencetak kode QR menggunakan bantuan library phpqrcode.

\subsection{Pengujian dan pembahasan}

Pengujian kepada sistem informasi pelayanan servis komputer dilakukan dengan menggunakan metode blackbox. Pengujian blackbox berfokus pada persyaratan fungsional perangkat lunak. Dengan demikian, pengujian blackbox memungkinkan perekayasa perangkat lunak mendapatkan serangkaian kondisi input yang sepenuhnya menggunakan semua persyaratan fungsional untuk suatu program ${ }^{[5]}$. Pada akhir pengujian kita dapat menganalisa kelemahan dan kekurangan yang dimiliki oleh sistem untuk segera diperbaiki.

Fungsi dan fitur yang dimiliki sistem informasi pelayanan servis komputer berbasis QR code telah melewati pengujian, mulai dari melakukan input invoice, melakukkan pemindaian kode QR yang ada pada nota transaksi sampai dengan melakukan cetak laporan transaksi. Pengujian yang dilakukan dapat dilihat pada tabel 2

Tabel 2. Pengujian Sistem Informasi

\begin{tabular}{|c|l|l|}
\hline $\begin{array}{c}\text { No } \\
\cdot\end{array}$ & \multicolumn{1}{|c|}{ Pengujian } & $\begin{array}{c}\text { Keteranga } \\
\text { n }\end{array}$ \\
\hline 1. & $\begin{array}{l}\text { Fungsi mencari no } \\
\text { transaksi }\end{array}$ & Berhasil \\
\hline 2. & $\begin{array}{l}\text { Fungsi melakukan } \\
\text { login }\end{array}$ & Berhasil \\
\hline 3. & $\begin{array}{l}\text { Fungsi, menambahkan, } \\
\text { menghapus, } \\
\text { mengupdate data } \\
\text { transasksi }\end{array}$ & Berhasil \\
\hline
\end{tabular}




\begin{tabular}{|l|l|l|}
\hline 4. & $\begin{array}{l}\text { Fungsi menambahkan, } \\
\text { mengedit, mengaous } \\
\text { user admin dan staff. }\end{array}$ & Berhasil \\
\hline 5. & $\begin{array}{l}\text { Fungsi mencetak nota } \\
\text { transaksi }\end{array}$ & Berhasil \\
\hline 6. & $\begin{array}{l}\text { Fungsi mencetak } \\
\text { laporan transaksi }\end{array}$ & Berhasil \\
\hline 7. & $\begin{array}{l}\text { Fungsi mengubah } \\
\text { informasi sistem }\end{array}$ & Berhasil \\
\hline 8. & $\begin{array}{l}\text { Fungsi kode QR untuk } \\
\text { di pindai }\end{array}$ & Berhasil \\
\hline 9. & $\begin{array}{l}\text { Fungsi } \\
\text { menambahkan,menged } \\
\text { it, menghapus daftar } \\
\text { harga }\end{array}$ & Berhasil \\
\hline 10. & $\begin{array}{l}\text { Fungsi melihat data } \\
\text { transaksi selesai }\end{array}$ & Berhasil \\
\hline
\end{tabular}

Pertanyaan serta kode kuisioner.

P1 : $\quad$ Sistem informasi pelayanan servis komputer sudah banyak

P2 : Tampilan sistem ini mudah di pahami

P3 : Setiap fungsi pada sistem ini mudah digunakan

P4 : Dengan adanya sistem informasi nantinya dapat meningkatkan pelayanan kepada pelanggan ditempat anda

P5 : Dalam usaha pelayanan servis komputer sistem informasi sangat diperlukan

Ketentuan nilai dapat dilihat pada tabel 3.

Tabel 3. Tabel nilai kuisioner

\begin{tabular}{|l|l|l|}
\hline $\begin{array}{l}\text { SS = } \\
\text { Sangat } \\
\text { Setuju (5) }\end{array}$ & $\begin{array}{l}\text { S = Setuju } \\
(4)\end{array}$ & $\begin{array}{l}\text { KS = } \\
\text { Kurang } \\
\text { Setuju (3) }\end{array}$ \\
\hline $\begin{array}{l}\text { TS = } \\
\text { Setuju (2) }\end{array}$ & $\begin{array}{l}\text { STS = } \\
\text { Sangat } \\
\text { Tidak } \\
\text { Setuju (1) }\end{array}$ & \\
\hline
\end{tabular}

Perhitungan kuisinoer dilakukan dengan menggunakan rumus 1 .

$$
\text { Presentase }=\frac{\text { jumlah nilai } \times 100 \%}{\text { nilai maksimal }}
$$

Nilai maksimal dihitung dengan menggunakan rumus 2 .

Nilai maksimal $=$ Jumlah Pengisi $x 5$

Nilai maksimal $=6 \times 5=30$

Hasil pengujian pada pelaku usaha servis komputer dapat dilihat pada tabel 4 .

Tabel 4. Tabel kuisioner pengujian sistem

\begin{tabular}{|c|c|c|c|c|c|c|c|}
\hline \multirow{5}{*}{$\begin{array}{c}\text { K } \\
\text { o } \\
\text { de }\end{array}$} & \multicolumn{5}{|c|}{ Jawaban } & $\mathbf{J u}$ & \multirow[b]{2}{*}{ Pres } \\
\hline & \multirow{4}{*}{$\begin{array}{l}\text { S } \\
\text { S( } \\
5)\end{array}$} & $\mathbf{S}$ & $\mathbf{K}$ & \multicolumn{2}{|r|}{ ST } & \multirow{4}{*}{$\begin{array}{c}\text { ml } \\
\text { ah } \\
\text { Nil } \\
\text { ai }\end{array}$} & \\
\hline & & ( & $\mathbf{S}($ & $\mathbf{S}($ & $\mathbf{S}($ & & \multirow{3}{*}{$\begin{array}{c}\text { enta } \\
\text { se }\end{array}$} \\
\hline & & 4 & 3) & 2) & 1) & & \\
\hline & & ) & & & & & \\
\hline $\mathrm{P}$ & \multirow[t]{2}{*}{0} & \multirow[t]{2}{*}{4} & \multirow[t]{2}{*}{2} & \multirow[t]{2}{*}{0} & \multirow[t]{2}{*}{0} & \multirow[t]{2}{*}{22} & 73,3 \\
\hline 1 & & & & & & & $3 \%$ \\
\hline $\mathrm{P}$ & \multirow[t]{2}{*}{2} & \multirow[t]{2}{*}{4} & \multirow[t]{2}{*}{0} & \multirow[t]{2}{*}{0} & \multirow[t]{2}{*}{0} & \multirow[t]{2}{*}{26} & 86,6 \\
\hline 2 & & & & & & & $6 \%$ \\
\hline $\mathrm{P}$ & \multirow[t]{2}{*}{2} & \multirow[t]{2}{*}{4} & \multirow[t]{2}{*}{0} & \multirow[t]{2}{*}{0} & \multirow[t]{2}{*}{0} & \multirow[t]{2}{*}{26} & 86,6 \\
\hline 3 & & & & & & & $6 \%$ \\
\hline $\mathrm{P}$ & \multirow[t]{2}{*}{4} & \multirow[t]{2}{*}{2} & \multirow[t]{2}{*}{0} & \multirow[t]{2}{*}{0} & \multirow[t]{2}{*}{0} & \multirow[t]{2}{*}{28} & 93,3 \\
\hline 4 & & & & & & & $3 \%$ \\
\hline $\mathrm{P}$ & \multirow[t]{2}{*}{4} & \multirow[t]{2}{*}{2} & \multirow[t]{2}{*}{0} & \multirow[t]{2}{*}{0} & 0 & 28 & 93,3 \\
\hline 5 & & & & & & & $3 \%$ \\
\hline & & u & ata & ene & ase & & 86,6 \\
\hline & & & & & & & $6 \%$ \\
\hline
\end{tabular}

Berdasarkan tabel diatas P1 mendapatkan presentase nilai $73,33 \%$, yang artinya sistem informasi dalam dunia usaha pelayanan servis komputer sudah ada. Tampilan dari sistem yang di buat juga mudah dipahami dan fungsi pada sistem juga mudah digunakan dengan presentase P2 dan P3 sama sama memperoleh $86,66 \%$. Pelaku usaha servis komputer menyadari dengan adanya sistem informasi dapat meningkatkan pelayanan kepada pelanggan dan sistem informasi sangat diperlukan terlihat dari hasil P4 dan P5 yang mendapatkan nilai 93,33\%. Sedangkan rata - 
rata presentase membuktikan bahwa sistem informasi dapat diterapkan dalam usaha pelayanan servis komputer dan dapat meningkatkan pelayanan kepada pelanggan

\section{KESIMPULAN}

Sistem infomasi berbasis web dapat diterpakan dalam usaha pelayanan servis komputer ini dapat dilihat dengan presentase $86,66 \%$ dari pelau usaha servis komputer yang menjawab kuisioner, pelaku usaha komputer menyadari penggunaan sistem informasi dapat meingkatkan pelayanan kepada pelanggan hal ini dapat dilihat dari hasil presentase kuisioner.

Sistem informasi yang dibuat juga dapat berjalan dengan baik penggunaan kode $Q R$ sebagai fitur juga mudah dipahami dan digunakan oleh pelaku usaha servis komputer. Sistem informasi yang mudah digunakan dan fitur yang unik dapat menambah lagi minat pelaku usaha servis komputer untuk menggunakan sistem informasi berbasis web.

\section{REFERENSI}

[1] I.T.Asare, and D. Asare (2015). "The Effective Use of Quick Response (QR) Code as a Marketing Tool '. International Journal of Education and Social Scince, vol. 2, No.12,pp 67-73.

[2] I.Binanto (2014), "Analisa Metode Classic Life Cycyle (Waterfall) Untuk Pengembangan Perangkat Lunak Multimedia". Confrence: Seminar Nasional Sains dan Teknologi Informasi (SeNasti) 2014 At Makassar, ISBN: 23550536X, pp. 67-73.
[3] B.Khumar, N.Sharma, and N.Yadav (2014). "Educational Application of $Q R$ (Quick Response) Code”. International Journal of Advanced Research in Computer Science \& Technology (IJARCST), e-ISSN : 2347-8446, pp.373-375.

[4] Rajeeva.KR, \& BM.Sagar (2014). "Quick Response code for Fast Detection and Recognition Information". International Journal of Emerging Techmlogy and Advanced Engineering, ISSN: 2250-2459, vol.4,no,2,pp.271-275

[5] R.S.Pressman (2012). "Rekayasa Perangkat Lunak - Buku Satu, Pendekatan Praktisi (Edisi 7)", Penerbit Andi, Yogyakarta,

[6] J.Simamarta (2006), "Pengenalan Teknologi Komputer dan Informasi", Penerbit Andi Offset, Yogyakarta.

[7] H.Supriyono, N.A.Saputro, and R.A.Prasetya, (2016). "Rancang Bangun Sistem Informasi Manajemen Presensi Berbasis SMS Gateway (Studi Kasus : SMP Muhammadiyah 1 Kartasura)". The $3^{\text {rd }}$ University Research Coloquim 2016. ISSN : 2407-9189.

[8] T.Sutabri (2013). "Analisis Sistem Informasi", Penerbit Andi Offset, Yogyakarta/

[9] A.L.Yudanto, H.Tolle, and A.H.Brata, 2017. "Rancang Bangun Apliksi Sistem Informasi Manajemen Laboratorium Biomedik Fakultas Kedokteran Universitas Brawijaya”, Jurnal Pengembangan Teknologi Informasi dan Ilmu Komputer, e-ISSN: 2548-964X, vol.1, no.8, pp.628-634. 